\title{
Interactive comment on "A Decade of Variability on Jakobshavn Isbrae: Ocean Temperatures Pace Speed Through Influence on Mélange Rigidity" by lan Joughin et al.
}

\section{Anonymous Referee \#2}

Received and published: 4 October 2019

Joughin et al. presents here a manuscript about the variability of Jakobshavn Isbrae using dense time series of speed and surface elevation over the period 2009-2019. The main conclusion is that the front advances and retreats of Jakobshavn, which is the major forcing for seasonal fluctuations of the glacier (in terms of thickening/thinning and acceleration) is controlled by the rigidity of the mélange and not submarine melt as proposed in previous studies. If true, this could have major implications about the main mechanism leading to rapid retreats of tidewater glaciers around glacier and therefore projection of the evolution of the Greenland Ice Sheets. A other major conclusion concerns the steep ice cliff of Jakobshavn that are not collapsing contrary to the instability mechanism proposed for the rapid retreat of the ice sheet. Finally they provide inter- 
esting insights into calving mechanism through the formation of basal crevasses that seems to initiate necking process leading the future large calving.

They are no questions about the quality of data collected and processed here. It is quite a impressive work. The conclusions about the basal crevassing and the absence of ice cliff failure seem robust. My main concern comes from the conclusion on the mélange rigidity versus submarine melt as forcings for the calving rate and so terminus position. Indeed, submarine melt rate stated in Khazendar et al. 2019 are 2 orders of magnitude smaller than those used here. I believe that 8-10 m/yr (line 276) should actually read 8-10 m/day as in Fig. 3a from Khazendar et al.. Values for submarine melt of tidewater glaciers published in other studies (Sciascia et al. 2013, Slater et al. 2018, Sutherland et al. 2019, etc. .) are similar to those of Khazendar et al., which consequently, although not perfect, seem realistic. The proper melt rate of 8-10 $\mathrm{m} / \mathrm{day}$ is therefore about one third of the ice motion at terminus (30-45 m/day) and it becomes obvious that the ice is not replenished "far faster" that the melting (as stated in line 284) and therefore could potentially lead to the undercutting process proposed and sometimes observed in other studies (Sutherland et al. 2019). Considering this, the authors can absolutely not rule out that submarine is a main driver in controlling the terminus position. In addition, the observations of "strong" mélange during period of advance and weak mélange during retreat could be just coincidental as ice mélange is most probably weak during period of high submarine melt and vice-versa. The discussion would also be strengthened if recent modeling studies and mechanisms that would prevent ice calving in the presence of ice mélange were included (such as Krug et al. 2015). The last comment is about the implications for other glaciers in Greenland that is not mentioned in the paper. The presence of such "thick" mélange is particular to Jakobshavn Isbrae, where icebergs are well confined in a long fjord. Glaciers along NW coast also display seasonal variations but it is less obvious that such a thick ice mélange is present for these glaciers that are more open on the ocean. Would the presence of relatively thin sea ice also have the same impact on the calving rate ?

Printer-friendly version

Discussion paper

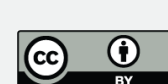


That said I still believe that the discussion about the mélange rigidity is interesting and it is possible that both mechanisms (submarine melt and ice mélange) are influencing the calving rate. I appreciate the effort made for gathering and processing all these datasets and the interesting conclusions on the formation of basal crevasse and ice cliff failure. I would therefore recommend revision of the paper according the above comments and much milder conclusion on the influence of submarine melt vs ice mélange concentration.

Khazendar, A., Fenty, I. G., Carroll, D., Gardner, A., Lee, C. M., Fukumori, I., et al. (2019). Interruption of two decades of Jakobshavn Isbrae acceleration and thinning as regional ocean cools. Nature Geoscience, 12(4), 277-283. https://doi.org/10.1038/s41561-019-0329-3

Krug, J., Durand, G., Gagliardini, O., and Weiss, J.: Modelling the impact of submarine frontal melting and ice mélange on glacier dynamics, The Cryosphere, 9, 989-1003, https://doi.org/10.5194/tc-9-989-2015, 2015.

Sciascia, R., Straneo, F., Cenedese, C., and Heimbach, P. ( 2013), Seasonal variability of submarine melt rate and circulation in an East Greenland fjord, J. Geophys. Res. Oceans, 118, 2492- 2506, doi:10.1002/jgrc.20142.

Slater, D. A., Straneo, F., Das, S. B., Richards, C. G., Wagner, T. J. W., \& Nienow, P. W. (2018). Localized Plumes Drive FrontâǍŘWide Ocean Melting of A Greenlandic Tidewater Glacier. Geophysical Research Letters, 45(22), 12,350-12,358. https://doi.org/10.1029/2018GL080763

Slater, D. A., Straneo, F., Das, S. B., Richards, C. G., Wagner, T. J. W., \& Nienow, P. W. (2018). Localized plumes drive front-wide ocean melting of a Greenlandic tidewater glacier. Geophysical Research Letters, 45, 12,350-12,358. https://doi.org/10.1029/2018GL080763 